ISSN: 1858-4837; E-ISSN: 2598-019X

Volume 15, Nomor 2 (2020),

https://jurnal.uns.ac.id/region

DOI: 10.20961/region.v15i2.29694

\title{
Modal sosial dalam ketahanan komunitas terhadap bencana banjir di Kelurahan Kemijen dan Krobokan, Kota Semarang
}

\author{
Social capital in community resilience to flooding disaster in Kemijen and \\ Krobokan Sub-District, Semarang City
}

\author{
A D Norzistya ${ }^{1}$, W Handayani $^{1}$ \\ ${ }^{1}$ Departemen Perencanaan Wilayah dan Kota, Fakultas Teknik, Universitas \\ Diponegoro
}

Corresponding author's email: vindadn@gmail.com

Abstrak. Berdasarkan letak geografisnya, Kota Semarang sering dilanda bencana
banjir dan rob. Manajemen bencana telah dilakukan di wilayah ini tetapi masih
bersifat teknis. Aspek sosial jarang diperhatikan dalam tahapan manajemen bencana.
Hal ini tentunya berdampak pada ketahanan komunitasnya dalam merespon dan
menyerap dampak terhadap bencana banjir. Membangun ketahanan komunitas
bergantung pada hubungan sosial, jaringan, dan keterhubungan di antara komunitas.
Beberapa faktor tersebut terdapat pada modal sosial sebagai sumberdaya potensial
yang dapat menstimulasi berbagai fungsi yang terikat dalam struktur sosial.
Penelitian ini bertujuan untuk mengkaji ketahanan komunitas terhadap manajemen
bencana banjir di Kelurahan Kemijen dan Krobokan yang dilihat dari sejauh mana
nilai-nilai modal sosial yang tertanam pada Kelurahan Siaga Bencana (KSB). Ini
didukung dengan menggunakan pendekatan campuran antara kuantitatif yang
menggunakan metode survei serta kualitatif menggunakan metode case study.
Pendekatan campuran ini didukung dengan metode analisis skoring, normalisasi, dan
deskripsi. Hasil penelitian menunjukkan bahwa terdapat perbedaan nilai modal sosial
pada KSB Kemijen dan Krobokan dalam manajemen bencana banjir. Perbedaan
terlihat pada nilai bonding dan bridging di KSB Kemijen lebih kuat dibandingkan
dengan KSB Krobokan. Salah satunya dipengaruhi oleh keaktifan anggota komunitas
dalam mengikuti tahap kesiapsiagaan bencana banjir. Namun, kondisi tersebut tidak
mengurangi modal sosial di KSB Krobokan dalam manajemen bencana banjir salah
satunya dipengaruhi oleh peran ketua KSB yang selalu menginformasikan terkait
kebencanaan. Selain itu, keberadaan institusi lokal sebagai media dalam
meningkatkan modal sosial di kedua KSB. Modal sosial yang tertanam pada KSB

Received: April 26, 2019; Accepted: June 11, 2019; Available online: July 31, 2020

Copyright $\odot$ 2020, REGION: Jurnal Pembangunan Wilayah dan Perencanaan Partisipatif 
berperan dalam ketahanan komunitas Kelurahan Kemijen dan Krobokan dalam manajemen bencana banjir.

Kata Kunci: Ketahanan Komunitas; Kota Semarang; Manajemen Bencana; Modal Sosial

\begin{abstract}
Based on its geographical, Semarang City frequently hit by flood and rob disaster. Disaster managements have been carried out in this area but only the technical aspect. Social aspect is rarely discussed in the disaster management. This certainly has an impact on the resilience of the community in receiving and responding to the effects of the flood disaster, from time of the disaster to the post disaster. Building community resilience depends on social relations and networking between communities. These factors are found on social capital as a potential resource that can stimulate various functions to social structures. This research examines community resilience to flood disaster management in Kemijen and Krobokan Sub-district which is seen from the extent of the values of social capital embedded in the Kelurahan Siaga Bencana (KSB). This study uses a mixed approach, quantitative by survey methods and qualitative by case study. This approach is supported by scoring, normalization, and description analysis methods. The result shows that there is a difference between the values of social capital in the KSB Kemijen dan Krobokan in flood disaster management. The difference seen in the value of bonding and bridging in KSB Kemijen which is stronger than in KSB Krobokan. One of the influences is the activeness of community members in following the flood disaster preparedness stage. However, these condition didn't reduce social capital embedded. One of the reasons is because of the role of the KSB chairman who always informs about disaster related matters. In addition, the existence of local institutions as a media in increasing social capital in both KSB. Social capital embedded in KSB plays a role in the community resilience of Kemijen and Krobokan Sub-district in flood disaster management.
\end{abstract}

Keywords: Community Resilience; Disaster Management; Semarang City; Social Capital

\title{
1. Pendahuluan
}

Pemikiran tentang konsep ketahanan komunitas dalam manajemen bencana terus berkembang dalam beberapa tahun terakhir. Misalnya UNISDR [1], pendekatan komunitas untuk manajemen darurat [2], dan kampanye PBB dalam membuat kota berketahanan [3]. Ketahanan komunitas adalah suatu proses yang menghubungkan jaringan kapasitas adaptif dengan pembelajaran yang kolektif [4] dan penggunaan kapasitas tersebut dipahami sebagai kondisi yang melekat pada individu dan komunitas dalam menghadapi bencana [5-6]. Meningkatnya minat pada ketahanan sebagai sebuah konsep yang telah menghasilkan banyak definisi [7]. Ini diperkuat dengan adanya globalisasi, perubahan iklim, hilangnya keanekaragaman hayati, dan bencana yang disebabkan oleh aktivitas manusia serta proses alam [8]. Komunitas di daerah rawan bencana menjadi bagian yang selalu rentan terhadap 
peristiwa yang ekstrim dan umumnya tidak dapat dicegah tetapi hanya dapat diminimalkan risiko yang terjadi [9]. Komunitas yang memiliki daya tahan yang kuat akan lebih mampu mempertahankan struktur dan fungsi sosial dasarnya [10]. Di tingkat komunitas, kapasitas sosial muncul sebagai hal penting untuk menangani bencana seperti jejaring sosial [11], partisipasi [12], organisasi dan kerjasama [13]. Ini memungkinkan tindakan kolektif terhadap keputusan kebutuhan dasar yang terancam oleh bencana. Namun, kapasitas ini sering diabaikan oleh perencana karena terlalu menekankan pada aspek ketahanan fisik dan ekonomi daripada aspek ketahanan sosial. Saat bencana terjadi di suatu wilayah maka akan mengakibatkan timbulnya berbagai dampak seperti rumah atau bangunan yang hancur, kehilangan mata pencaharian, jaringan sosial yang terpecah, pemisahan keluarga hingga kematian. Bencana gempa bumi dan tsunami yang terjadi di Aceh, Indonesia pada tahun 2004 ini telah menghancurkan sebagian wilayah Aceh yang mengakibatkan ratusan ribu jiwa meninggal dan lebih dari 750.000 jiwa kehilangan mata pencaharian menunjukkan besarnya kerugian yang ditimbulkan oleh bencana ini [14]. Kerugian yang dihasilkan juga tergantung terhadap kapasitas atau kemampuan untuk mencegah maupun menghindar beserta daya tahannya. Menurut Nakagawa dan Shaw [15] dalam kasus gempa Kobe, Jepang tahun 1995 bahwa sebagian besar korban selamat karena adanya tindakan cepat tanggap yang diambil oleh anggota komunitasnya. Ini menunjukkan bahwa komunitas yang terinformasi dengan baik yang memiliki kesadaran tingkat tinggi dan pengetahuan terkait kesiapsiagaan dan mitigasi bencana. Oleh karena itu, membangun ketahanan komunitas telah menjadi bagian dari manajemen bencana.

Saat ini bencana dianggap sebagai fenomena yang sporadis tetapi harus dikelola dan diminimalisirkan secara optimal [16]. Upaya mengurangi dampak bencana yang terjadi diperlukan kerjasama dalam jaringan yang mengimplementasikan pada kegiatan manajemen bencana di semua tingkatan komunitas, organisasi pelaksana, dan sektor pemerinah [17]. Konsep yang ditawarkan oleh Abulnour [18\} memandang bahwa manajemen bencana tidak hanya fokus pada pemenuhan kebutuhan dan kesenjangan saat prabencana melainkan juga fokus pada pembangunan karakter kapasitas masyarakat. Gotong royong menjadi senjata yang ampuh dalam kalangan komunitas saat menanggulangi bencana karena kombinasi antara kerjasama dan solidaritas antar sesamanya. Rijanta dkk [19] menyatakan bahwa aksi komunitas dalam mengurangi risiko bencana merupakan aspek penting untuk menjaga kearifan lokal dan nilai tindakan sebagai sumber dan bentuk modal sosial.

Modal sosial menjadi salah satu faktor penting dalam manajemen bencana [20]. Modal sosial di tingkat komunitas dan jaringan sosialnya (social network) adalah bagian penting dari upaya manajemen bencana. Seringkali modal sosial di tingkat komunitas dan jaringan sosial yang sudah ada diabaikan oleh pembuat kebijakan dalam manajemen bencana. Kim, dkk [21] menggambarkan bahwa upaya mengatasi peran modal sosial dalam manajemen bencana mengacu pada konsep ketahanan komunitas. Modal sosial menyatukan orang-orang yang memiliki kesamaan dalam hal penting untuk menghadapi masalah dan mencari solusi dari permasalahan tersebut. Keterlibatan komunitas didapat melalui penguatan modal sosial di lingkungannya menjadi faktor utama dalam keberhasilan penerapan konsep ketahanan 
(resilient). Chong, dkk [22] menyatakan bahwa apabila suatu komunitas dengan modal sosial yang kuat cenderung menunjukkan semangat ketahanan yang lebih kuat juga dan begitu sebaliknya apabila suatu komunitas dengan modal sosial yang rendah maka ketahanannya pun akan cenderung rendah. Modal sosial terjadi ketika adanya interaksi sosial antar anggota komunitas yang sangat kuat sehingga secara tidak langsung saling menumbuhkan kepercayaan satu sama lain. Portes [23] mendeskripsikan interaksi sosial tersebut membentuk sebuah bonding social capital dan selanjutnya akan membentuk bridging social capital manakala terjadi interaksi yang heterogen dan menciptakan suatu linking social capital (keterhubungan).

Studi yang dilakukan oleh Aldrich \& Meyer [24] menyatakan bahwa pengembangan bridging social capital didapat dari penggunaan bonding social capital dalam fase pemulihan. Bonding social capital yang kuat ketika anggota komunitas cenderung bergantung pada dukungan dari individu di dalam komunitasnya. Salah satunya pertemuan focus group dan acara sosial ini dalam meningkatkan bonding social capital yang ada antar individu di dalam komunitasnya. Selanjutnya, ketika anggota komunitas menyadari bahwa sumber dayanya tidak cukup untuk membangun kembali lingkungan dan komunitasnya maka terjadi pelanggaran jaringan sosialnya dengan harapan bahwa kerjasama dengan komunitas lain dapat menyediakan sumber daya yang diperlukan. Hal ini memungkinkan komunitas untuk berorganisasi setelah terjadinya bencana. Oleh karena itu, modal sosial telah ditemukan sebagai alat dalam membangun dan memperkuat ketahanan komunitas sebelum suatu peristiwa yang merugikan. Penelitian yang dilakukan oleh Petzold dan Ratter [25] mendeskripsikan jika bonding social capital berkontribusi terhadap ketahanan komunitas dengan mendorong anggota komunitas untuk mempromosikan dan berbagi pengetahuan dan keterampilan yang berperan dalam membantu komunitas mengatasi perubahan iklim.

Kota Semarang secara geografis berada di pesisir utara Provinsi Jawa Tengah yang dilalui oleh dua sungai besar yaitu Sungai Banjir Kanal Barat dan Sungai Banjir Kanal Timur. Kondisi ini yang menyebabkan wilayah ini seringkali terjadi bencana banjir dan rob. Saat musim hujan, muara sungai tersebut meluap dan menggenangi permukiman yang lokasinya berada di dekat bantaran sungai. Selain itu, banjir yang terjadi juga diakibatkan oleh kenaikan muka air laut atau disebut dengan rob. Fenomena banjir rob ini sudah terjadi sejak lama dan diperparah seiring dengan terjadinya perubahan iklim. Salah satu wilayahnya yaitu di Kelurahan Kemijen dengan tingkat risiko bencana banjir tinggi yang mengalami banjir dan rob. Beberapa penelitian terdahulu yang pernah dilakukan oleh Kencana dan Yuliastuti [26] dan Fauzie dan Sariffuddin [27] menghasilkan temuan secara umum masyarakat di Kelurahan Kemijen pada tahap sebelum dan sesudah terjadinya bencana banjir memiliki inisiatif lokal dengan memanfaatkan sumber daya yang ada. Masyarakat sudah memiliki inisiatif dalam membuat atau mengusulkan program dan menerapkannya, salah satunya dengan adanya bentuk adaptasi masyarakat terhadap huniannya melalui peninggian lantai dan membuat barrier. Sementara secara historis Kota Semarang pernah dilanda banjir bandang salah satunya di Kelurahan Krobokan yang secara geografis bersebelahan dengan Sungai Banjir Kanal Barat. Meskipun Kelurahan Krobokan sudah mulai menurun frekuensi 
terjadinya banjir akan tetapi jika musim hujan tiba dengan intensitas tinggi, wilayah ini masih terdapat banjir di beberapa lokasi. Penelitian yang dilakukan oleh Yesiana, dkk [28] menunjukkan masyarakat Krobokan memiliki inisiatif dalam program kegiatan kebersihan lingkungan dan sosialisasi kepada warganya terkait pentingnya kesiapsiagaan bencana. Sosialisasi ini dilakukan saat adanya rapat formal yang biasanya dilakukan mingguan maupun bulanan. Hal ini bertujuan agar masyarakat memiliki sikap kesiapsiagaan dalam menghadapi ancaman bencana. Dengan pertimbangan sebelumnya maka masyarakat baik yang tinggal di daerah rawan bencana banjir tinggi maupun rendah perlu memiliki pemahaman terkait manajemen bencana. Dengan demikian, penelitian ini lebih difokuskan pada Kelurahan Kemijen dan Krobokan.

Pemerintah Kota Semarang telah bergabung ke dalam program 100 Resilient City (100RC) untuk menangani risiko bencana yang terjadi. Bergabungnya Kota Semarang ke dalam program 100RC paling tidak telah meminimalisir persoalan bencana banjir yang terjadi. Namun, implementasi program tersebut hanya berfokus pada pembangunan infrastruktur dan masih menyisahkan permasalahan sosial [29]. Selanjutnya, program tersebut dilanjutkan dari berbagai lembaga yang membantu Kota Semarang mewujudkan ketahanan melalui BPBD Kota Semarang membentuk Kelurahan Tangguh Bencana (Katana). Salah satu programnya membentuk Kelurahan Siaga Bencana (KSB) sebagai aksi komunitas cepat tanggap dalam menghadapi bencana. Berbagai upaya yang telah dilakukan Pemerintah Kota Semarang dalam mengatasi bencana banjir akan tetapi realisasinya tidak sepenuhnya optimal. Salah satu strategi dalam manajamen bencana banjir yaitu membentuk kelompok dalam masyarakat atau komunitas untuk menangani permasalahan tersebut [30]. Munculnya komunitas yang memiliki kesadaran sosial ini memperlihatkan bahwa masih terdapat nilai-nilai di dalam sistem sosial. Keberadaan komunitas di kawasan bencana banjir ini tersimpan modal sosial yang terus dipertahankan.

Tujuan dari penelitian ini adalah untuk mengelaborasi modal sosial dalam mendorong ketahanan komunitas di KSB Kemijen dan Krobokan dalam manajemen bencana banjir. Ketahanan komunitas ini dilihat dari sejauh mana nilai-nilai modal sosial yang tertanam dalam manajemen bencana banjir. Penelitian ini juga mengadopsi dari Sanyal dan Routray [20] bahwa modal sosial dalam manajemen bencana terjadi karena adanya bonding, bridging, dan linking social capital. Berdasarkan beberapa penelitian tersebut maka penelitian ini akan melihat modal sosial yang ada di Kelurahan Siaga Bencana (KSB) dalam manajemen bencana banjir di Kelurahan Kemijen dan Krobokan. Dengan demikian, adanya penelitian ini diharapkan dapat menjadi bahan pertimbangan dalam memberikan rekomendasi dan perencanaan yang tepat pada wilayah tersebut.

\section{Metode}

\subsection{Metode penelitian}

Penelitian ini menggunakan metode campuran (mix method) yang merupakan kombinasi antara kuantitatif dan kualitatif. Creswell [31] mendefinisikan metode campuran akan bermanfaat apabila metode kualitatif maupun kuantitatif secara masing-masing tidak cukup 
akurat digunakan untuk memahami permasalahan penelitian. Jenis metode yang diambil adalah metode eksplanatoris yang menurut Creswell [32] mendefinisikan sebagai desain dalam metode campuran dengan latar belakang kuantitatif yang kuat dan dilanjutkan ke kualitatif. Tujuan dari metode campuran eksplanatoris untuk mengelaborasi modal sosial pada KSB dalam manajemen bencana banjir.

Tahap pertama yaitu penelitian kuantitatif yang difokuskan pada bagaimana nilai modal sosial pada ketahanan komunitas dalam manajemen bencana banjir. Tahap kedua yaitu penelitian kualitatif yang mengeskplorasi mendalam hasil dari perhitungan. Singkatnya, prosesnya melibatkan pengumpulan data survei pada tahap pertama, menganalisis data, dan menindaklanjuti dengan wawancara kualitatif untuk membantu menjelaskan tanggapan survei. Pada penelitian kuantitatif menggunakan metode survei dan penelitian kualitatif menggunakan metode studi kasus. Latar belakang pemilihan metode campuran sebagai berikut:

- Penilaian modal sosial dibutuhkan suatu perhitungan yang didapatkan dari persepsi atau pendapat dari anggota komunitas (Kelurahan Siaga Bencana/KSB) tentang manajemen bencana banjir yang datanya berupa kuantitatif dari hasil kuesioner

- Untuk memperkuat nilai modal sosial tersebut dibutuhkan data kualitatif berupa wawancara untuk membantu menjelaskan secara lebih rinci hasil perhitungan kuantitatif.

- Untuk mengetahui ketahanan komunitas melalui program KSB maka dibutuhkan data terkait sejarah dan perkembangan KSB yang datanya berupa kualitatif dari hasil wawancara dan data sekunder dari suvei instansi.

\subsection{Metode pengumpulan data}

Metode pengumpulan data pada penelitian ini terdiri dari dua yaitu metode pengumpulan data primer dan data sekunder. Pengumpulan data primer ini dilakukan dengan penyebaran kuesioner ke anggota komunitas KSB Kemijen dan Krobokan. Teknik analisis yang digunakan teknik non probability sampling dengan sampling jenuh. Sementara untuk wawancara menggunakan purposive sampling yang berfokus sesuai dengan tujuan dan sasaan penelitian yaitu BPBD Kota Semarang dan ketua KSB karena dianggap lebih mengerti mengenai KSB. Pengumpulan data sekunder dilakukan dengan telaah dokumen dan survei instansi terkait.

\subsection{Teknik analisis data}

Teknik analisis data yang digunakan dalam penelitian ini adalah analisis skoring dan deskriptif. Analisis deskriptif adalah menyajikan data secara sistematis sehingga mendapatkan gambaran wilayah studi dengan jelas. Analisis skoring untuk mengetahui sejauh mana nilai modal yang tertanam pada KSB Kemijen dan Krobokan. Dalam penentuan skor berdasarkan skala Likert yang dapat digunakan untuk mengukur sikap, persepsi, maupun pendapat responden terhadap variabel penelitian. Pada penelitian ini akan menggunakan beberapa variabel yang terpilih dari hasil studi literatur dan dihubungkan dengan kondisi lapangan yang ada. Aspek dan variabel yang digunakan dalam penelitian dapat dilihat pada Gambar 1. 


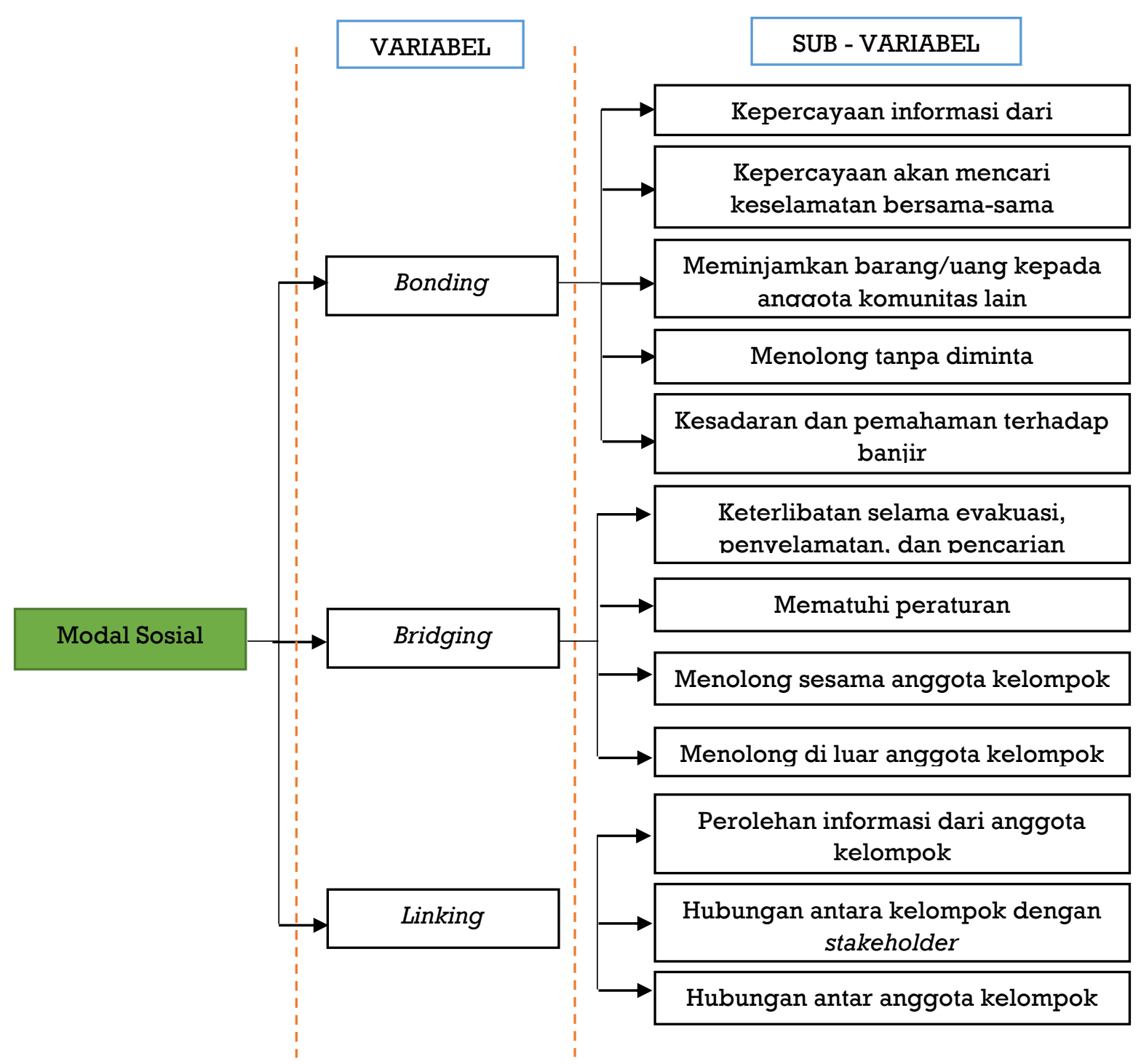

Gambar 1. Aspek dan variabel yang digunakan dalam penelitian [20].

Untuk menghitung skor yang ada di setiap variabel menggunakan skala Likert dari jenjang skor 1 hingga 5. Klasifikasi variabel skala likert dapat dilihat pada Gambar 1.

Tabel 1. Klasifikasi variabel skala likert.

\begin{tabular}{ccccc}
\hline $\begin{array}{c}\text { Sangat Tidak } \\
\text { Setuju }\end{array}$ & $\begin{array}{c}\text { Tidak Setuju } \\
\text { (TS) }\end{array}$ & Netral & Setuju & Sangat Setuju \\
\hline 1 & 2 & 3 & 4 & 5 \\
\hline Tidak Pernah & Jarang & Kadang & Sering & Selalu \\
\hline 1 & 2 & 3 & 4 & 5 \\
\hline $\begin{array}{c}\text { Sangat Tidak } \\
\text { Puas }\end{array}$ & Tidak Puas & Biasa & Puas & Sangat Puas \\
\hline 1 & 2 & 3 & 4 & 5 \\
\hline
\end{tabular}

Received: April 26, 2019; Accepted: June 11, 2019; Available online: July 31, 2020 
Selanjutnya dilakukan analisis normalisasi untuk mendukung dalam analisis membandingkan antara modal sosial di KSB Kemijen dengan KSB Krobokan pada ketahanan komunitas dalam upaya manajemen bencana banjir. Perhitungan normalisasi dilakukan setelah analisis skoring setiap variabel telah selesai dilakukan. Pengukuran normalisasi dilakukan dengan menggunakan metode Min-Max sebagai berikut:

Keterangan:

$$
\text { Normalisasi }=\frac{(\text { Data }- \text { Min }) *(\text { New Max }- \text { New Min })}{(\text { Max }- \text { Min })+\text { New Min }}
$$

$\begin{array}{ll}\text { Data } & \text { : Nilai Variabel (Rata-Rata Skor) } \\ \text { Min } & \text { : Nilai Terendah Indikator } \\ \text { Max } & \text { : Nilai Tertinggi Indikator } \\ \text { New Min } & \text { : Batas Minimum yang Diberikan } \\ \text { New Max } & \text { : Batas Maksimum yang Diberikan } \\ \text { Sumber: Nasution, dkk }\end{array}$

Sumber: Nasution, dkk [33]

Adapun perhitungan skala interval pada pengkategorian sebagai berikut:

$$
\text { Rentang skor }=\frac{\text { Skor tertinggi }- \text { skor terendah }}{\text { Jumlah jenjang skor }}
$$

Sangat Rendah: $0,00-0,20$

Rendah $: 0,21-0,40$

Sedang $\quad: 0,41-0,60$

Kuat $\quad: 0,61-0,80$

Sangat Kuat $: 0,81-1,00$

\section{Hasil Penelitian dan Pembahasan}

\subsection{Modal sosial pada ketahanan komunitas}

Ketahanan komunitas tergantung pada hubungan sosial, jaringan, dan keterhubungan di antara komunitas. Dalam pola hubungan yang terjadi maka terikat oleh kepercayaan, kesaling pengertian, dan nilai-nilai bersama yang nantinya membangun sebuah jaringan untuk mencapai tujuan bersama. Modal sosial membuat suatu komunitas bersama-sama dalam menghadapi bencana hingga mereka dapat bertahan dalam menghadapi bencana tersebut. Modal sosial sebagai salah satu alat komunitas dapat mengakses sumberdaya melalui suatu hubungan. Hubungan yang terjadi adanya interaksi sosial ini terdapat dua jenis yaitu yang bersifat homogen dan heterogon [23]. Interaksi homogen dalam komunitas terjadi antar anggota komunitas dan akan membentuk modal sosial yang mengikat (bonding social capital) sedangkan interaksi heterogen terjadi antara anggota komunitas dengan non komunitas yang akan membentuk bridging social capital. Menurut Sanyal \& Routray [20] modal sosial terbagi menjadi tiga jenis utama yaitu bonding, bridging, dan linking dengan ketiganya saling berhubung satu sama lain. Oleh karena itu peran modal sosial sangat penting dalam menghadapi bencana sehingga komunitas dapat bertahan. 
KSB Kemijen dan KSB Krobokan telah mengalami ketahanan yang diperlihatkan pada setiap tahunnya terkena guncangan dan tekanan akibat bencana banjir meskipun kedua wilayah memiliki tingkat tekanan dan guncangan yang berbeda. Kondisi tersebut dipengaruhi oleh beberapa faktor salah satunya terbentuknya modal sosial di kedua KSB. Modal sosial di KSB Kemijen terjalin karena adanya hubungan sosial kemasyarakatan yang erat dan mereka menganggap hubungan tersebut seperti kekeluargaan. Sementara di KSB Krobokan terbentuk modal sosial karena jiwa sosial yang tinggi pada beberapa anggota komunitasnya terkait perolehanan informasi. Namun, hubungan di luar komunitas di KSB Kemijen terlihat rendah dibandingkan di KSB Krobokan karena mereka menanggap perolehan informasi hanya sebatas saat terjadinya banjir dan rob saja. Dengan demikian, modal sosial sangat penting untuk diketahui karena salah satu kunci menentukan keberlangsungan manajemen bencana banjir. Ini tentunya terbentuk karena adanya saling percaya, norma yang terbentuk, dan terjalinnya suatu jaringan antar anggota komunitas. Bentuk-bentuk modal sosial di KSB Krobokan dan KSB Kemijen sebagai berikut:

3.1.1 Bonding social capital. Bonding social capital atau modal sosial yang mengikat merupakan ikatan antar individu dalam kondisi dan situasi yang sama. Bonding social capital yang kuat ketika anggota komunitas cenderung bergantung pada dukungan dari individu di komunitasnya [24]. Bonding ini dapat dilihat dengan fakta di lapangan yang menunjukkan kedua komunitas tersebut memiliki hubungan yang dibangun atas dasar kepercayaan yang saling kuat dan sikap yang saling mendukung satu sama lain. Nilai bonding yang terikat di KSB Kemijen lebih kuat dibandingkan di KSB Krobokan dikarenakan kehidupan bermasyarakat KSB Kemijen lebih erat dan lebih bersifat kekeluargaan disebabkan adanya perasaan senasib. Kondisi tersebut juga menimbulkan adanya rasa solidaritas dan kooperatif yang terjadi di KSB Kemijen. Hal ini sejalan yang dikatakan oleh Fukuyama [34] bahwa unsur terpenting dalam modal sosial dengan membangun bonding yang dilandasi oleh kepercayaan yang dapat memperkuat rasa solidaritas dan sifat kooperatif dalam komunitas. Nilai-nilai tersebut kurang terjalin di KSB Krobokan karena masih adanya beberapa anggota komunitas yang tidak aktif dalam kegiatan manajemen bencana sehingga kehidupan sosial kemasyarakatannya kurang begitu erat. Meskipun begitu kedua KSB beranggapan bahwa kepercayaan informasi dari kelompok karena dianggap sebagai modal penting untuk saling menjaga dan melindungi ketika terjadi suatu permasalahan. Saling percaya membuat masyarakat dapat hidup dengan nyaman karena anggota komunitasnya dapat dipercaya tidak akan melakukan hal-hal yang negatif. Sementara indikator kesadaran dan pemahaman tentang banjir dinilai sangat diperlukan karena dari pemahaman tersebut diharapkan dapat meminimalkan korban dan kerugian akibat bencana di masa mendatang. Dari kesadaran ini secara tidak langsung akan membentuk suatu tindakan menyelamatkan orang tanpa diminta mengingat bencana banjir akan berdampak secara luas baik ekonomi, sosial, maupun lingkungan. Perilaku menolong tanpa diminta memiliki nilai tertinggi juga karena membantu meningkatkan kebahagiaan orang lain. Perhitungan skoring bonding social capital dapat dilihat pada Tabel 2. 
Tabel 2. Perhitungan skoring bonding social capital.

\begin{tabular}{|c|c|c|c|}
\hline Indikator & Kode & $\begin{array}{c}\text { KSB } \\
\text { Krobokan }\end{array}$ & KSB Kemijen \\
\hline Percaya pada informasi dari kelompok & $\mathrm{C} 3$ & 1,13 & 1,17 \\
\hline $\begin{array}{l}\text { Meminjamkan barang/uang kepada anggota } \\
\text { komunitas lain }\end{array}$ & F1 & 1,10 & 1,12 \\
\hline $\begin{array}{l}\text { Percaya akan mencari keselamatan bersama- } \\
\text { sama }\end{array}$ & E2 & 0,79 & 0,73 \\
\hline Menolong tanna diminta & D1 & 1,16 & 1,17 \\
\hline IVIenorong tanpa aımınta & $\mathrm{D} 2$ & 0,87 & 1,02 \\
\hline Kesadaran dan pemahaman terhadap banjir & $\mathrm{C} 4$ & 1,18 & 1,12 \\
\hline $\begin{array}{l}\text { Keterlibatan kelompok dalam kegiatan } \\
\text { preventif banjir }\end{array}$ & $\mathrm{C} 8$ & 0,78 & 0,66 \\
\hline $\begin{array}{c}\text { Normalisasi } \\
\text { Kategori }\end{array}$ & & $\begin{array}{l}0,56 \\
\text { Sedang }\end{array}$ & $\begin{array}{l}0,66 \\
\text { Kuat }\end{array}$ \\
\hline
\end{tabular}

*Keterangan

Perhitungan di atas sudah terstandarisasi

$\begin{array}{ll}\text { Sangat Rendah } & : 0,00-0,20 \\ \text { Rendah } & : 0,21-0,40 \\ \text { Sedang } & : 0,41-0,60 \\ \text { Kuat } & : 0,61-0,80 \\ \text { Sangat Kuat } & : 0,81-1,00\end{array}$

3.1.2 Bridging social capital. Bridging social capital atau modal sosial yang menjembatani adalah suatu ikatan yang lebih luas antar beberapa individu tanpa adanya hubungan emosional. Menurut Aldrich \& Meyer [24] pengembangan bridging social capital didapat dari penggunaan bonding social capital dalam fase pemulihan. Adanya bridging ini memanfaatkan koneksi sebagai upaya pemulihan yang lebih cepat dan baik. Analisis bridging pada KSB Kemijen dan KSB Krobokan dilihat dari keterlibatan selama evakuasi, penyelamatan, dan pencarian, mematuhi peraturan, menolong sesama anggota komunitas, serta menolong di luar anggota komunitas. Bridging ini terlihat pada KSB Kemijen yang sudah menetapkan tiap lokasi evakuasi terdapat lima orang lapangan yang memantau kondisi di masing-masing lokasi. Orang-orang tersebut sebagai perantara dan sumber utama KSB Kemijen dalam kegiatan evakuasi. Titik-titik lokasi evakuasi di Kelurahan Kemijen sebanyak lima titik lokasi yaitu di balai kelurahan, SD Kemijen 3, SD Kemijen 1, balai RW V, dan Masjid Dipo Indah. Kondisi tersebut terjadi juga di KSB Krobokan bahwa selama kegiatan evakuasi anggota komunitas khususnya pada bidang evakuasi terlibat aktif dalam usaha pencarian dan penyelamatan. Adapun titik-titik lokasi evakuasi sebanyak tiga lokasi yaitu kantor pemadam kebakaran dan Masjid At Taklom, Masjid Al Jihad, serta Mushala Al Hikmah. Berbagai upaya dalam bridging social capital yang tak lepas dari penggunaan bonding dalam fase pemulihan. Anggota komunitas menyadari bahwa sumber dayanya tidak 
cukup untuk membangun kembali lingkungan dan komunitasnya sehingga perlu adanya dukungan dari luar komunitas.

Nilai bridging yang terikat di KSB Kemijen lebih kuat dibandingkan di KSB Krobokan dikarenakan pada KSB Kemijen menilai rasa saling tolong-menolong tidak terbatas pada kedekatan saja melainkan membantu orang lain di luar komunitas perlu dilakukan. Hal ini berguna untuk mengoptimalkan potensinya dan membuka peluang potensi yang ada di luar komunitasnya dan tentunya akan mendorong kemajuan dan pengembangan individu dalam suatu komunitas. KSB Kemijen beranggapan juga jika mematuhi peraturan ini akan menciptakan kedisiplinan masing-masing anggotanya dan nantinya akan berubah menjadi suatu kebiasaan serta percaya akan merasakan manfaatnya. Hal ini juga dikemukakan oleh Hasbullah [35] sebuah modal sosial yang akan berkembang kuat jika di dalamnya ditunjang oleh nilai dan norma yang terbentuk di dalam kehidupan bermasyarakat. Nilai dan norma ini dapat bersifat tertulis maupun tidak tertulis di dalam suatu komunitas. Fedderke, dkk [36] menyebutkan juga jika norma sebagai elemen penting modal sosial yang di dalamnya berupa aturan-aturan informal dan nilai-nilai yang memfasilitasi adanya koordinasi di antara anggota dalam sebuah sistem sosial. Dari kondisi tersebut maka didapatkan pandangan bahwa KSB Kemijen lebih memiliki nilai kehidupan sosial bermasyarakat karena adanya suatu peraturan yang dapat mengikat mereka. Sementara pada KSB Krobokan memiliki nilai jiwa sosial yang kuat pada masing-masing individu akan tetapi hubungan di dalam komunitasnya kurang begitu kuat karena masih adanya beberapa anggota yang tidak aktif sehingga dalam menjalin hubungan sosialnya tentuya belum bisa erat. Hal ini yang menjadi dasar bahwa indikator menolong di luar anggota komunitas lebih tinggi baik dibandingkan dengan KSB Kemijen maupun antar indikatornya. Meskipun hubungan yang terjalin di dalam komunitas KSB Krobokan masih rendah akan tetapi mereka menjalin interaksi di luar komunitasnya yang bersifat heterogen sehingga dalam manajemen bencana banjir dapat berjalan dengan baik. Perhitungan skoring bridging social capital dapat dilihat pada Tabel 3.

Tabel 3. Perhitungan skoring bridging social capital.

\begin{tabular}{lccc}
\hline \multicolumn{1}{c}{ Indikator } & Kode & KSB Krobokan & KSB Kemijen \\
\hline $\begin{array}{l}\text { Keterlibatan selama evakuasi, penyelamatan, } \\
\text { dan pencarian }\end{array}$ & D4 & 0,97 & 1,16 \\
Mematuhi peraturan & F10 & 1,08 & 1,16 \\
Menolong sesama anggota komunitas & D1 & 0,77 & 0,68 \\
Menolong di luar anggota komunitas & D2 & 1,17 & 1,15 \\
$\quad$ Normalisasi & D3 & 1,01 & 0,85 \\
$\quad$ Kategori & & $\mathbf{0 , 5 8}$ & $\mathbf{0 , 6 7}$ \\
& & Sedang & Kuat \\
\hline
\end{tabular}

*Keterangan

Perhitungan di atas sudah terstandarisasi

Sangat Rendah $\quad: 0,00-0,20$ 


$\begin{array}{ll}\text { Rendah } & : 0,21-0,40 \\ \text { Sedang } & : 0,41-0,60 \\ \text { Kuat } & : 0,61-0,80 \\ \text { Sangat Kuat } & : 0,81-1,00\end{array}$

3.1.3 Linking social capital. Analisis linking social capital di KSB Kemijen dan KSB Krobokan ditunjukkan bagaimana hubungan suatu komunitas dengan komunitas lain maupun stakeholder dalam memanfaatkan sumber daya yang tersedia di luar komunitasnya. Jaringan dan relasi tidak terbatas pada yang bersifat horizontal melainkan juga yang bersifat vertikal sebagai upaya dinamis bagi komunitas dalam manajemen risiko bencana banjir. Semakin banyak jaringan yang dimiliki maka kebutuhan hidupnya juga akan semakin mudah didapatkan. Menurut Sanyal \& Routray [20] beranggapan linking social capital terjadi tergantung pada apakah komunitas memiliki hubungan dengan orang-orang di pemerintahan atau pemegang kekuasaan lainnya. Linking yang tercipta di kedua KSB tergolong kuat tetapi jika dilihat perolehan rata-ratanya bahwa KSB Kemijen lebih tinggi dibandingkan di KSB Krobokan. Kondisi ini terjadi karena keaktifan ketua di kedua KSB dalam memperoleh informasi. Perolehan informasi ini didasari saling percaya antar anggota komunitasnya. Stone dan Hughes [37] menyatakan juga bahwa jaringan sosial (linking) diukur salah satunya dengan adanya ikatan informal yang memiliki karakteristik yaitu kepercayaan dan hubungan timbal balik yang bersifat lebih personal seperti kekeluargaan, pertemanan, maupun pertetanggaan. Ini menunjukkan linking yang terbangun dari komunikasi antar individu yang menfokuskan pada pertukaran informasi sebagai sebuah proses untuk mencapai tindakan, kesepakatan, dan pengertian bersama. Selain itu semangat jiwa sosial dari ketua KSB yang selalu memberikan informasi terbaru tak hanya bencana banjir saja melainkan berbagai bencana yang kemungkinan akan terjadi di Kota Semarang. Sementara untuk hubungan dengan stakeholder di kedua KSB menjadi indikator paling rendah karena di KSB Kemijen menganggap peran stakeholder yang dinilai masih kurang dalam hal perolehan informasi maupun bantuan. Perhitungan skoring linking social capital dapat dilihat pada Tabel 4.

Tabel 4. Perhitungan skoring linking social capital.

\begin{tabular}{cccc}
\hline \multicolumn{1}{c}{ Indikator } & Kode & KSB Krobokan & KSB Kemijen \\
\hline Perolehan informasi dari anggota komunitas & $\mathrm{C} 1$ & 1,04 & 1,03 \\
Hubungan antar anggota komunitas & $\mathrm{F} 11$ & 1,02 & 1,03 \\
Hubungan antara komunitas dengan stakeholder & $\mathrm{F} 12$ & 0,94 & 0,93 \\
Normalisasi & & $\mathbf{0 , 6 1}$ & $\mathbf{0 , 6 7}$ \\
Kategori & & Kuat & Kuat \\
\hline
\end{tabular}

*Keterangan

Perhitungan di atas sudah terstandarisasi

$\begin{array}{ll}\text { Sangat Rendah } & : 0,00-0,20 \\ \text { Rendah } & : 0,21-0,40 \\ \text { Sedang } & : 0,41-0,60\end{array}$

Received: April 26, 2019; Accepted: June 11, 2019; Available online: July 31, 2020 217

Copyright @ 2020, REGION: Jurnal Pembangunan Wilayah dan Perencanaan Partisipatif 
Kuat $\quad: 0,61-0,80$

Sangat Kuat $\quad: 0,81-1,00$

\subsection{Keterhubungan modal sosial pada ketahanan komunitas dalam manajemen bencana} banjir.

Komunitas di Kelurahan Kemijen dan Krobokan yang tinggal di sekitar daerah rawan bencana tidak membuat mereka takut untuk tinggal di daerah tersebut. Beberapa alasan yang membuat komunitas tetap tinggal di wilayah ini seperti sudah lama bermukim, kedekatan dengan tempat kerja maupun keluarganya, pengaruh nilai lahan, dll. Kondisi tersebut tentunya menjadikan komunitas berketahanan karena permasalahan banjir dan rob menjadi bagian dari normalitas sehari-hari. Pondasi ketahanan komunitas di Kelurahan Kemijen dan Krobokan ini melalui suatu kelompok yang memainkan peran dalam keseluruhan informasi kebencanaan. Peran KSB ini dielaborasi sebagaimana tujuan awal dibentuknya KSB oleh BPBD yaitu mengurangi tingkat risiko bencana dengan cara memberdayakan komunitasnya. Ketahanan komunitas tidak dapat terwujud jika komunitasnya tidak melakukannya secara bersama-sama. Membangun ketahanan komunitas bergantung pada hubungan sosial, jaringan dan keterhubungan antar komunitasnya. Beberapa faktor tersebut terdapat pada modal sosial sebagai sumberdaya yang potensial yang menstimulasi dalam manajemen bencana. Beberapa cara yang dilakukan komunitas di Kelurahan Kemijen dan Krobokan dalam meningkatkan modal sosial dalam ketahanan komunitas antara lain:

3.2.1 Interaksi sosial sebagai elemen dasar modal sosial. Interaksi sosial sebagai investasi individu dalam membangun sumberdaya sosial. Portes [23] mendeskripsikan terdapat dua jenis interaksi sosial yaitu homogen dan heterogen yang menghasilkan bentuk modal sosial yang berbeda. Interaksi sosial homogen terjadi antar anggota komunitas yang membentuk bonding social capital. Bonding ini memainkan peran di komunitas Kelurahan Kemijen dan Krobokan ketika sebelum terjadinya bencana yaitu pengumpulan informasi dan saat kejadian bencana ditunjukkan pada mengorganisir relawan, meningkatkan kesadaran, dan memberikan akses peluang yang ada. Ketika dirasa bonding social capital ini belum mampu membangun ketahanan komunitas maka komunitas di Kelurahan Kemijen dan Krobokan meminta bantuan di luar komunitasnya yang secara tidak langsung membentuk suatu interaksi sosial yang bersifat heterogen. Interaksi sosial heterogen membentuk bridging social capital yang terjadi antara anggota komunitas dan non komunitas. Bridging social capital memainkan peran di komunitas Kelurahan Kemijen dan Krobokan selama masa evakuasi, penyelamatan, dan pencarian sebagai upaya yang lebih cepat dan baik. Hal ini ditunjukkan pada masing-masing wilayah yang sudah menetapkan titik-titik lokasi evakuasi supaya alur distribusi penyelamatan lebih efisien dan efektif. Selama kegiatan evakuasi, penyelamatan, dan pencarian komunitas di kedua wilayah dengan saling tolong menolong baik sesama anggota komunitas maupun di luar komunitasnya. Ketika bentuk bantuan berupa makanan (mentah) maka alur pendistribusian dimulai dari dapur umum yang dimasak terlebih dahulu kemudian dibagikan ke masing-masing titik lokasi evakuasi melalui tim evakuasi dari KSB atau masing-masing RW. Kondisi ini menunjukkan pentingnya bridging di antara anggota komunitas yang mempengaruhi sejauh mana akan tindakan kooperatif 
untuk membangun kembali komunitas yang berketahanan. Ini menyiratkan bahwa anggota komunitas sering memanfaatkan bridging-nya untuk mendapatkan bantuan yang nantinya mengarah pada bantuan bersama untuk seluruh komunitas. Dengan demikian, interaksi sosial menghasilkan bonding yang menyediakan kondisi untuk munculnya bridging social capital bahwa individu cenderung untuk berinteraksi secara homogen terlebih dahulu kemudian anggota komunitasnya cenderung termotivasi untuk membangun interaksi sosial yang heterogen.

3.2.2 Peran ketua KSB. Penelitian yang telah dilakukan oleh Nakagawa dan Shaw [15] bahwa peran pemimpin komunitas sebagai cara yang paling efektif dalam memanfaatkan modal sosial. Kejadian bencana banjir dan rob yang terjadi di Kelurahan Kemijen dan Krobokan ini tidak dapat diprediksi sehingga komunitas melalui KSB telah memiliki sistem peringatan bencana. Komunitas sudah mulai mengandalkan informasi kebencanaan melalui sistem peringatan dini yang bersumber salah satunya dari ketua KSB. Sistem peringatan dini merupakan sistem yang memberitahukan ketika akan timbul suatu bahaya atau bencana. Saat ini sistem yang ada di dua wilayah tersebut menggunakan platform WhatsApp grup yang sumber informasi didapatkan dari ketua KSB. Ketua KSB akan memberitahukan segala informasi kebencanaan yang mungkin terjadi di wilayahnya maupun di Kota Semarang supaya warganya memiliki sikap waspada terhadap segala bentuk bencana. Dari ketua KSB ini akan menginformasikan kepada masing-masing RW dan dilanjutkan ke masing-masing RT dan terakhir berada di warganya. Kapasitas komunitas untuk mendapatkan informasi terpercaya melalui koneksi jaringan yang kemudian merefleksikannya melalui kompetensi dan menanggapi masalah dengan cepat yang muncul melalui pemberdayaan. Karakteristik perilaku komunitas ini merupakan bagian dari modal sosial yang menfasilitasi tindakan kolektif untuk saling menguntungkan. Modal sosial yang tertanam dalam KSB membuat komunitas yang memiliki kekuatan maka akan membantu komunitas yang lemah seperti anak-anak maupun usia lanjut.

3.2.3 Institusi lokal sebagai media sosial. Dalam mengukur ketahanan komunitas memberikan persepsi terkait kemampuan komunitas mengatasi untuk pengambilan keputusan hingga keadaan yang paling darurat. Untuk itu perlu keterlibatan komunitas dengan pola mengkombinasikan peran serta melalui pertemuan focus group dan acara sosial berlaku dalam masyarakat [24]. Hal ini sejalan juga yang diungkapkan oleh Fedderke, dkk [36] bahwa sebuah asosiasi sosial di dalamnya mengandung norma-norma berupa aturan informal dan nilai-nilai yang menfasilitasi adanya koordinasi di antara anggota dalam sebuah sistem sosial. Asosiasi yang ada di Kelurahan Kemijen dan Krobokan dalam bentuk kegiatan perkumpulan warganya yang diadakan setiap bulannya mulai dari karang taruna, arisan RT maupun RW, pengajian, hingga rapat KSB. Adanya kegiatan-kegiatan tersebut menunjukkan sense of community seperti rasa kebersamaan dan hubungan sosial kemasyarakatan yang terjalin [38]. Keberadaan institusi lokal tersebut cukup efektif dalam menumbuhkembangkan modal sosial yang memicu timbulnya rasa kebersamaan dan saling percaya. Sikap ini terjadi di Kelurahan Kemijen saat terjadinya bencana rob di akhir bulan Januari tahun 2019 bahwa komunitas Kemijen dengan segera bertindak cepat tanggap dalam upaya menanggulangi 
bencana rob. Komunitas saling bergotong royong membuat talud sementara dengan menggunakan karung-karung goni yang diisi pasir untuk mengurangi debit volume banjir yang akan masuk ke permukimannya. Kondisi ini tidak terlepas adanya bantuan dari KSB Kemijen yang membantu upaya menanggulangi bencana rob saat itu dengan meminta bantuan ke BPBD Kota Semarang. Bantuan dari BPBD ini mengirimkan empat truk kontainer air yang bertujuan membersihkan lumpur yang telah menggenangi di lingkungan permukiman yang terkena rob. Tindakan tersebut tentunya adanya modal sosial yang tertanam antara komunitas dengan KSB Kemijen sebagai bentuk ketahanan komunitas.

3.2.4 Kebijakan formal dan informal. Salah satu parameter penting dalam mewujudkan kesiapsiagaan dengan adanya kebijakan sebagai acuan dalam pelaksanaannya. Kerangka kebijakan yang mengatur aturan-aturan formal serta nilai dan norma yang terbentuk di dalam kehidupan masyarakat ini dapat membentuk sebuah modal sosial [35]. Dalam parameter ini menekankan pada peran pemerintah sebagai pembuat kebijakan yang berkoordinasi dengan dinas terkait dalam pembentukan kelurahan siaga bencana (KSB). Peran KSB ini dilibatkan dalam keseluruhan proses manajemen bencana banjir dan rob yang telah tertuang dalam program kelurahan seperti materi kesiapsiagaan, adanya simulasi, dan terbentuknya tim siaga bencana. Keberadaan program-program tersebut di komunitas Kemijen dan Krobokan menjadikan komunitas tidak lagi menganggap bencana banjir dan rob sebagai sesuatu hal yang menakutkan yang tidak bisa dihindari. Peningkatan pengetahuan, pemahaman, dan sikap dalam komunitas Kelurahan Kemijen dan Krobokan dijalankan selaras dengan kearifan lokal yang ada. Selain itu, adanya KSB baik di Kemijen maupun Krobokan membuat komunitasnya bisa lebih cepat tanggap baik sebelum terjadinya bencana maupun saat terjadi bencana banjir dan rob. Hal ini ditunjukkan oleh kehadiran komunitas dalam kegiatan pelatihan, sosialisasi, maupun simulasi yang diberikan oleh BPBD Kota Semarang. Meskipun ada sebagian komunitas di Kelurahan Krobokan yang belum terlibat dalam pelaksanaan program tersebut akan tetapi kondisi tersebut tidak mengurangi dalam sikap kesiapsiagaan dan cepat tanggap dalam menghadapi bencana banjir.

Kebijakan tidak hanya aturan-aturan formal saja melainkan juga terdapat aturan-aturan informal yang dapat membentuk sebuah modal sosial pada ketahanan komunitas. Aturanaturan informal ini biasanya dalam bentuk nilai dan norma yang tercipta dalam kehidupan bermasyarakat [36]. Diketahui bahwa di Kelurahan Kemijen dan Krobokan memiliki sense of community yang membentuk solidaritas karena adanya bonding social capital yang mendorong kepatuhan aturan dan kebiasaan sekaligus mengurangi kebutuhan untuk pengaturan formal. Berdasarkan kondisi tersebut jika terjadi ancaman bencana banjir maupun rob secara tiba-tiba, komunitas di kedua wilayah tersebut tidak perlu menunggu untuk dikomando melainkan mengambil tindakan secara tanggap darurat saling bergotongroyong dan memberikan bantuan secara sukarelawan.

\section{Kesimpulan}

Studi ini telah memberikan penilaian komparatif pertanyaan berdasarkan persepsi dan bukti untuk memeriksa kapasitas KSB. Pondasi ketahanan komunitas di Kelurahan Kemijen dan 
Krobokan ini melalui suatu kelompok yang memainkan peran dalam keseluruhan informasi kebencanaan. Peran KSB ini dielaborasi sebagaimana tujuan awal dibentuknya KSB oleh BPBD Kota Semarang. Penelitian ini telah mengelaborasi modal sosial pada ketahanan komunitas yang memiliki perbedaan di kedua KSB. Pada KBS Kemijen memiliki hubungan modal sosial yang kuat pada semua aspek sedangkan di KSB Krobokan, modal sosial yang kuat hanya pada aspek linking saja. Hal ini dikarenakan keaktifan ketua KSB dalam memperoleh informasi. Perolehan informasi ini didasari saling percaya antar anggota komunitasnya. KSB Kemijen dan KSB Krobokan menunjukkan berbagai bentuk modal sosial yaitu pada tingkat bonding social capital adanya koneksi internal di dalam komunitas berdasarkan kepercayaan dan norma yang menciptakan keinginan untuk tercapainya tujuan bersama. Bonding ini sebagai dasar dalam penentuan bridging dan linking. Namun, dalam tahapan manajemen bencana banjir untuk keaktifan anggota di KSB Krobokan dinilai masih rendah dalam tingkat partisipasi dan keterlibatan kegiatan preventif terhadap banjir. Berkat bonding yang tercipta antar anggota komunitas, komunitas ini terorganisasi dengan baik. Melalui semangat jiwa sosial KSB Kemijen yang menerapkan sifat hubungan kemasyarakatan ini merasa bencana banjir yang terjadi setiap tahunnya tidak memberikan rasa takut yang mendalam. Kondisi ini menimbulkan efek bahwa rasa saling tolong-menolong tidak terbatas pada kedekatan saja melainkan membantu orang lain di luar komunitasnya perlu dilakukan. Hal ini berguna untuk mengoptimalkan potensi dan membuka peluang potensi yang ada di luar komunitasnya serta tentunya akan mendorong kemajuan dan pengembangan individu dalam suatu komunitas. Dengan demikian, komunitas menunjukkan bridging social capital yang dapat menguntungkan linking di masa depan untuk komunitasnya.

Berdasarkan hasil perbandingan diketahui bahwa modal sosial yang kuat akan cenderung membentuk ketahanan komunitas yang kuat juga. Hal ini terjadi pada kedua KSB meskipun di KSB Krobokan masing-masing jenis modal sosialnya memiliki nilai yang berbeda akan tetapi tidak mempengaruhi ketahanan komunitasnya. Saat terjadi bencana banjir di Kelurahan Krobokan, anggota komunitas akan tetap saling bergotong-royong untuk bisa memulihkan keadaan sediakala. Hal ini tentunya didasari salah satunya adanya rasa saling percaya dan kesadaran dan pemahaman yang akan membentuk sikap saling tolongmenolong tanpa diminta. Beberapa indikator tersebut merupakan bagian dari modal sosial. Dalam meningkatkan modal sosial terhadap ketahanan komunitas melalui interaksi sosial, peran ketua KSB, institusi lokal, serta kebijakan formal dan informal.

\section{Ucapan Terima Kasih}

Ucapan rasa terima kasih penulis sampaikan kepada Departemen Perencanaan Wilayah dan Kota serta Laboratorium Pengembangan Wilayah dan Manajemen Lingkungan. Tidak lupa juga, penulis sampaikan rasa terima kasih kepada KSB serta Kelurahan Kemijen dan Krobokan sebagai narasumber yang telah membantu memberikan data dan informasi selama survai 


\section{Referensi}

[1] UNISDR 2005 Hyogo Framework for 2005-2015: Building the Resilience of Nations and Communities to Disaster United Nations International Strategy for Disaster Risk Reduction Diakses dari https://www.unisdr.org/2005/wcdr/intergover/officialdoc/L-docs/Hyogo-framework-for-action-english.pdf

[2] Federal Emergency Management Agency (FEMA) 2011 A Whole Community Approach to Emergency Management: Principles, Themes, and Pathways for Action FDOC 104-008-1 FEMA Diakses dari https://www.fema.gov/media-library-data/201307261813-25045-0649/whole_community_dec2011_2_.pdf

[3] UNISDR 2012 Making Cities Resilient Report 2012 My City is getting ready! A global snapshot of how local government reduce disaster risk The United Nations Office for Disaster Risk Reduction Diakses dari https://www.unisdr.org/files/28240_rcreport.pdf

[4] Norris F H, Stevens S P, Pfefferbaum B, Wyche K F dan Pfefferbaum R L 2008 Community Resilience as a Metaphor, Theory, Set of Capacities, and Strategy for Disaster Readiness Am Journal Community Psychol 41 1-2 pp 127-50 DOI: 10.1007/s10464-007-9156-6

[5] Boyd E, Osbahr H, Ericksen P J, Tompkins E L, Lemos M C dan Miller F 2008 Resilience and "Climatizing" Development: Examples and Policy Implications Development 513 pp 390-6 Diakses dari https://ideas.repec.org/a/pal/develp/v51y2008i3p390396.html

[6] Landau J dan Saul J 2004 Facilitating Family and Community Resilience in Response to Major Disaster In: Walsh F dan McGoldrick M (eds) Living Beyond Loss: Death in the Family 2nd ed pp 285-309 (New York: WW Norton \& Co) Diakses dari https://www.researchgate.net/publication/240626653_Facilitating_Family_and_Co mmunity_Resilence_in_Response_to_Major_Disaster

[7] Handayani W, Fisher M R, Rudiarto I, Setyono J S dan Foley D 2019 Operationalizing Resilience: A Content Analysis of Flood Disaster Planning in Two Coastal Cities in Central Java, Indonesia International Journal of Disaster Risk Reduction 35 DOI: 10.1016/J.IJDRR.2019.101073

[8] Wilson G A 2012 Community Resilience and Environmental Transition (London: Routledge)

[9] Morley P, Smith J S, Sangha K K, Sutton S dan Sithole B 2018 Evaluating Resilience in Two Remote Australian Communities Procedia Engineering 212 pp 1257-64 DOI: 10.1016/j.proeng.2018.01.162

[10] Kaluarachchi Y 2018 Building Community Resilience in the Re-settlement of Displaced Communities Procedia Engineering 212 pp 443-50 DOI: 10.1016/j.proeng.2018.01.057

[11] Aldrich D P 2012 Building Resilience: Social Capital in Post-Disaster Recovery (Chicago: University of Chicago Press) 
[12] Berkes F dan Turner N J 2006 Knowledge, Learning, and The Evaluation of Conservation Practice for Social-Ecological System Resilience Human Ecology 34 pp 479-494 Diakses dari https://link.springer.com/article/10.1007/s10745-006-9008-2

[13] Aldrich D P 2011 The Power of People: Social Capital's Role in Recovery from the 1995 Kobe Earthquake Natural Hazard 563 pp 595-611 DOI: 10.1007/s11069-010-9577-7

[14] Badan Rehabilitasi dan Rekonstruksi Aceh-Nias (BRR NAD-Nias) 2009 Laporan Akhir Dewan Pengarah Badan Rehabilitasi dan Rekonstruksi Wilayah dan Kehidupan Masyarakat Provinsi Nanggroe Aceh dan Kepulauan Nias Provinsi Sumatera Utara, tahun 2005-2009 (Aceh \& Nias: Dewan Pengarah BRR NAD-Nias)

[15] Nakagawa $Y$ dan Shaw R 2004 Social Capital: A Missing Link to Disaster Recovery International Journal of Mass Emergencies and Disaster 221 pp 5-34 Diakses dari https://www.researchgate.net/publication/255659714_Social_Capital_A_Missing_L ink_to_Disaster_Recovery

[16] Pramono M F, Lahuri S dan Ghozali M 2017 Penerapan Manajemen Krisis dalam Pengelolaan Bencana Longsor Banaran, Pulung, Ponorogo Journal of Social Dedication 11 pp 9-21 DOI: 10.21111/ku.v1i1.1418

[17] Provan K G dan Brinton M H 2003 Managing Networks Effectively Paper Presented at The National Public Management Research Conference (Washington DC: Georgetown University)

[18] Abulnour A H 2014 Towards Efficient Disaster Management in Egypt Housing and Building National Research Center 102 pp 117-26 DOI: 10.1016/j.hbrcj.2013.07.004

[19] Rijanta R, Hizbaron D R dan Baiquni M 2015 Modal Sosial dalam Manajemen Bencana (Yogyakarta: Gadjah Mada University Press)

[20] Sanyal S dan Routray J K 2016 Social capital for disaster risk reduction and management with empirical evidences from Sundarbans of India International Journal of Disaster Risk Reduction 19 pp 101-11 DOI: 10.1016/j.ijdrr.2016.08.010

[21] Kim C, Nakanishi H, Blackman D, Freyens B dan Benson A M 2017 The Effect of Social Capital on Community Co-Production: Towards Community-Oriented Development in Post-Disaster Recovery Procedia Engineering 180 pp 901-11 DOI: 10.1016/j.proeng.2017.04.251

[22] Chong N O, Kamarudin K H dan Wahid S N A 2018 Framework Consideration for Community Resilience Towards Disaster in Malaysia Procedia Engineering $212 \mathrm{pp}$ 165-72 DOI: 10.1016/j.proeng.2018.01.022

[23] Portes A 2000 Sosial Capital: Its Origins and Application in Modern Sociology Knowledge and Social Capital: Foundations and Applications ed Lesser E L (Oxford: Butterworth-Heinemann) chapter 324 pp 43-67 DOI: 10.1016/B978-0-7506-72221.50006-4

[24] Aldrich D P dan Meyer M 2015 Social Capital and Community Resilience American Behavioral Scientist 592 pp 254-269 DOI: 10.1177/0002764214550299

[25] Petzold J dan Ratter B M W 2015 Climate Change Adaptation Under A Social Capital Approach - An Analytical Framework for Small Islands Ocean and Coastal Management 112112 pp 36-43 DOI: 10.1016/j.ocecoaman.2015.05.003 
[26] Kencana A D dan Yuliastuti N 2016 Penilaian Bentuk Adaptasi Masyarakat Terhadap Hunian di Kawasan Rawan Rob dan Banjir Kelurahan Kemijen Jurnal Pengembangan Kota 42 pp 186-96 DOI: 10.14710/jpk.4.2.186-196

[27] Fauzie W Z dan Sariffudin S 2017 The Role Local Initiatives in Community Based Disaster Risk Management in Kemijen, Semarang IOP Conference Series: Earth and Environmental Science $70 \quad 012047 \quad$ Diakses dari https://iopscience.iop.org/article/10.1088/1755-1315/70/1/012047

[28] Yesiana R, Handayani W dan Anggraini M 2018 Pembentukan dan Penguatan Kelompok Siaga Bencana (KSB) sebagai Wujud Kesiapsiagaan Masyarakat Terhadap Banjir di Kanal Banjir Barat Kota Semarang Riptek 121 pp 113-28 Diakses dari https://bappeda.semarangkota.go.id/kategori/2/pembentukan-dan-penguatankelompok-siaga-bencana-(ksb)-sebagai-wujud-kesiapsiagaan-masyarakat-terhadapbanjir-di-kanal-banjir-barat-kota-semarang

[29] Warsilah H dkk 2018 Ketahanan Sosial dalam Kota Tangguh: Kajian Adaptasi Masyarakat terhadap Bencana Perubahan Iklim dan Banjir Rob di Kota Pesisir Semarang, Jawa Tengah (Jakarta: Pustaka Yayasan Obor Indonesia)

[30] Undang-Undang Nomor 24 Tahun 2007 tentang Penanggulangan Bencana Diakses dari https://bnpb.go.id/ppid/file/UU_24_2007.pdf pada 12-07-2020

[31] Creswell J W 2009 Research Design Pendekatan Penelitian Kualitatif, Kuantitatif, dan Mixed (Yogyakarta: Pustaka Pelajar)

[32] Creswell J W 2014 Research Design: Qualitative, Quantitative, and Mixed Methods Approaches: Fourth Design (London: Sage Publications) Diakses dari http://fe.unj.ac.id/wp-content/uploads/2019/08/Research-Design_QualitativeQuantitative-and-Mixed-Methods-Approaches.pdf

[33] Nasution D A, Khotimah H H dan Chamidah N 2019 Perbandingan Normalisasi Data Untuk Klasifikasi Wine Menggunakan Algoritma K-NN Journal of Computer Engineering System and Science 41 pp 78-82 DOI: 10.24114/cess.v4i1.11458

[34] Fukuyama F 1999 Social Capital and Civil Society (The Institute of Public Policy George Mason University) Diakses dari https://www.imf.org/external/pubs/ft/seminar/1999/reforms/fukuyama.htm

[35] Hasbullah J 2006 Social Capital: Menuju Keunggulan Budaya Masyarakat Indonesia (Jakarta: MR-United Press)

[36] Fedderke J, Kadt R D dan Luiz J 1999 Economic Growth and Social Capital: A Critical Reflection (Netherlands: Kluwer Academic Publisher) Diakses dari https://www.academia.edu/487017/Economic_growth_and_social_capital_A_critic al_reflection

[37] Stone W dan Hughes J 2002 Social Capital: Empirical Meaning and Measurement Validity Research Paper 27 (Australia: Australian Institute of Family Studies) Diakses dari https://apo.org.au/sites/default/files/resource-files/2002-07/apo-nid5682.pdf

[38] Kahne J dan Bailey K 1999 The Role of Social Capital in Youth Development: The Case of the "I Have A Dream" Program on Student Performance Educational Evaluation and Policy Analysis pp 78-90. Diakses dari https://doi.org/10.3102/01623737021003321 